\title{
THE ILluSION OF EQUALITY: THE FAILURE OF THE COMMUNITY PROPERTY REFORM TO ACHIEVE MANAGEMENT EQUALITY
}

\author{
ELIZABETH R. CARTER*
}

\section{INTRODUCTION}

Money is power. The fight for gender equality is, at its heart, a fight for both. In recent history, women have made significant strides in narrowing the moneygender gap, but we have been less successful in closing the gender-power gap. ${ }^{1}$ Scholars widely assumed that as women entered the workforce they would achieve economic parity with men. ${ }^{2}$ Indeed, women have made undeniable progress in closing the income and earnings gap between the sexes. ${ }^{3}$ What happens outside the home, however, does not tell the full story. "[E]arning money is not the same thing as controlling income." 4 A woman's, particularly a married woman's, ability to earn money does not necessarily correlate to her power to achieve equality at home or in society. "Regardless of how money is earned outside the home, only a minority of households manage money within the home in ways that equitably benefit both women and men," ${ }^{, 6}$ yet equal participation in financial decisions is desirable for a variety of reasons. Not only is equal participation in financial decisions more consistent with modern views of marriage as an egalitarian partnership, it appears to actually promote relationship stability. ${ }^{7}$ Equal participation also benefits society as whole by enabling women to participate fully in society and polity, thereby closing the gender-power gap. ${ }^{8}$

Sociologists use the term "allocative system" to describe what happens to

* Judge Anthony J. Graphia \& Jo Ann Graphia Associate Professor of Law, Louisiana State University. B.A., University of Memphis; J.D., Tulane University; LL.M. in Taxation, University of Alabama.

1. See Catherine T. Kenney, The Power of the Purse: Allocative Systems and Inequality in Couple Households, 20 GENDER \& SOC'Y 354, 359-62 (2006).

2. Id.

3. Andrée Peart Laney, Legal and Policy Issues Impacting Pay Equity, N.J. LAW., Feb. 2014, at 35 .

4. Kenney, supra note 1 , at 354 .

5. Id. at 357 .

6. Jeffrey Dew et al., Examining the Relationship Between Financial Issues and Divorce, 61 FAM. RELATIONS 615, 617 (2012).

7. Cybele Weisser, 7 Ways to Stop Fighting About Money and Grow Richer, Together, MONEY (June 1, 2014), http://time.com/money/2791658/couples-marriage-money-survey-femalebreadwinners/, archived at http://perma.cc/ZU3U-ASZN (describing how couples who share financial decisions are happier).

8. Mary Beth Franklin, Women Closing Financial Literacy Gender Gap, INVESTMENTNEWS (June 23, 2014), http://www.investmentnews.com/article/20140623/BLOG05/140629978/womenclosing-financial-literacy-gender-gap, archived at http://perma.cc/FJX9-ZGY5. 
money once it enters the home. ${ }^{9}$ Research suggests that the allocative system a couple employs is often a reflective of socio-economic demographics. ${ }^{10}$ Those allocative systems that are most common in the United States continue to work to the disadvantage of women. ${ }^{11}$ The law in most common law states expressly perpetuates this problem. ${ }^{12}$ Since the passage of the Married Women's Property Acts in the $1800 \mathrm{~s},{ }^{13}$ American common law jurisdictions have taken a hands-off approach to how spouses manage money once it is brought into the home. Legally, each spouse can manage the property titled in his or her name, and the spouses are free to title property in their names jointly. ${ }^{14}$ The practical and predictable consequence of this hands-off approach is that existing gender economic inequities are simply brought home.

The unequal participation in financial decisions by spouses in the American community property states is, however, more surprising. Beginning in the late 1960 s, the community property states abandoned gender-based management rules in favor of regimes that ostensibly granted women rights comparable to their husbands, thus furthering the community property view of marriage as an equal economic partnership between the spouses. ${ }^{15}$ With the exception of Texas, every community property jurisdiction adopted a legal regime that facially granted the spouses equal management rights over their community property. ${ }^{16}$ Why, then, is the law not reflected in the allocative systems spouses actually utilize in practice?

Perhaps it is. This Article argues that equal management does not exist in any important sense, and that the true goal of the equal management laws was never equality. Community property laws can no longer be honestly described as "a vehicle to ensure the devotion of the couple's resources to this unique partnership's purpose: the well-being and future prosperity of the family the couple creates" unless the wife and children are not considered a part of that family. ${ }^{17}$ Today, wives in community property states have no better rights than wives in separate property states. In some cases, their economic position may

9. See Kenney, supra note 1.

10. Id.

11. Id.

12. Id.

13. Married Women's Property Laws, LAW LIBRARY OF CONGRESS, http://memory.loc.gov/ ammem/awhhtml/awlaw3/property_law.html (last visited Jan. 12, 2014), archived at http://perma. cc/H4RC-PKA9.

14. Thomas M. Featherston, Jr., His, Her or Their Property: A Primer on Marital Property Law in the Community Property States, AMERICAN BAR ASSOCIATION (July 14, 2014), http://www.baylor.edu/law/faculty/doc.php/205011.pdf, archived at http://perma.cc/W8EA-TBW6.

15. Jo FreEman, Women: A Feminist Perspective 365-404 (1995).

16. See, e.g., LA. CIV. CodE ANN. art. 2364 (2014). "Each spouse acting alone may manage, control, or dispose of community property unless otherwise provided by law."

17. See Cynthia A. Samuel \& Katherine S. Spaht, Fixing What's Broke: Amending ERISA to Allow Community Property to Apply Upon the Death of a Participant's Spouse, 35 FAM. L. Q. 425, 432 (2001). 
even be worse.

Part I describes the various allocative systems identified by sociologists and provides empirical support for the importance of egalitarian management. Part II describes the historical development of the two legally sanctioned management regimes in the United States: the separate property regime and the community property regime. Part II also examines how spouses actually managed their money in the pre-1970s era. Part III argues that equality was not achieved in fact or in law. First, Part III relies on quantitative and qualitative research to demonstrate that equality was not achieved in fact. Then, Part III examines the history of the reform era and argues that equality was not the primary goal of the legal reforms. Part IV elaborates on this thesis and examines how the laws in effect today perpetuate inequality.

\section{Spousal Money Management: Allocative Systems}

The manner in which spouses actually manage their assets has always been more nuanced than the law suggests. To better describe what happens to money once it enters the home, sociologists have identified six distinct "allocative systems." " These allocative systems classify spousal money control and management along a continuum by reference to two factors. ${ }^{19}$ The first basis of classification looks at whether and to what extent the spouses combine their money into a common pot or account. ${ }^{20}$ Spouses may entirely combine their money into a common pot, they may keep their money entirely separate, or they may combine only a portion of their money. ${ }^{21}$ The second basis of classification considers which spouse has control over the money. ${ }^{22}$ One spouse may control all of the money or the spouses may jointly manage the money. ${ }^{23}$ At the spousal level, the manner in which spouses manage their money is an "indicator of the level of equality in a relationship." ${ }^{24}$ Spouses who share responsibility for managing money tend to exhibit greater equality in their relationships. ${ }^{25}$ In contrast, couples that vest management authority in one spouse alone are particularly unequal in their relationships. ${ }^{26}$ As a matter of public policy, equality should be our preference, and it should be reinforced by the law.

\section{A. Allocative Systems in General}

The six allocative systems identified by sociologists are: (1) separate

18. Kenney, supra note 1, at 359-62.

19. Id.

20. $I d$.

21. $I d$.

22. $I d$.

23. Id.

24. Carrie Yodanis \& Sean Lauer, Managing Money in Marriage: Multilevel and CrossNational Effects of the Breadwinner Role, 69 J. MARRIAGE \& FAM. 1307, 1307 (2007).

25. Id. at 1309.

26. Id. 
money/women's control; (2) separate money/men's control; (3) separate money/equal control; (4) pooled money/women's control; (5) pooled money/men's control; and (6) pooled money/equal control. ${ }^{27} \mathrm{~A}$ brief description of each follows.

1. Separate Money/Women's Control.-Spouses utilizing the separate money/women's control allocative system typically combine all of the wife's income, if any, with a portion of the husband's income into a single pot or account. ${ }^{28}$ The wife has control over that combined fund and uses it for household expenditures. ${ }^{29}$ The husband, however, retains a portion of his earnings for his own discretionary spending. ${ }^{30}$ "The implication of women's control, in conjunction with segregated money, is that most of the money for household spending is managed by the woman but that she does not have access to all of the man's earnings." 31 At first blush, the separate money/women's control allocative system appears to give the wife substantial control over the couple's finances and, in turn, control in the relationship. Research, however, suggests the exact opposite to be the case. ${ }^{32}$ Today, the separate money/women's control allocative system is most common in low-income households, "where there is insufficient money to meet the bills and the task is likely to be a chore or a burden rather than a source of power." ${ }^{33}$

2. Separate Money/Men's Control.-Under the separate money/men's control allocative system the husband retains control over his own earnings and is responsible for paying the household expenses. ${ }^{34}$ The wife typically has little or no income of her own and has no meaningful access to her husband's income. ${ }^{35}$ The husband may provide the wife with a "housekeeping allowance" so that she may buy groceries and perform other household errands. ${ }^{36}$ Research indicates that the separate money/men's control allocative system is particularly unequal and unfavorable to women with respect to women's access to personal spending money. ${ }^{37}$

3. Separate Money/Equal Control.-The separate money/equal control allocative system is sometimes referred to as a "partial pooling" system. ${ }^{38}$ Under this allocative system, money is segregated and each spouse controls his or her

27. Id.

28. See Kenney, supra note 1 , at 360.

29. Id.

30. $I d$.

31. Id.

32. Id.

33. Carolyn Volger et al., Intimate Relationships and Changing Patterns of Money Management at the Beginning of the Twenty-First Century, 57 BRIT. J. SOC. 455, 461 (2006).

34. Kenney, supra note 1 , at 360.

35. See id.

36. Id.

37. Id.

38. Id. 
funds independently. ${ }^{39}$ "[N]either partner has full access to the other's money, and household expenses are taken care of either by having each individual pay certain bills or by both pooling some portion of income for household expenses while each keeps his or her remaining income separate." ${ }^{\text {"0 }}$ The separate money/equal control allocative system is more common when both spouses are employed full-time and have higher income levels. ${ }^{41}$

4. Pooled Money/Women's Control.-The pooled money/women's control allocative system is one in which the spouses combine all of their money into a common pot that is controlled by the wife. ${ }^{42}$ Just like the separate money/women's control allocative system, the pooled money/women's control allocative system is less advantageous to women than its name suggests. The pooled money/women's control allocative system is associated with lowerincome households where controlling money is a chore rather than a source of power or independence. ${ }^{43}$

5. Pooled Money/Men's Control.-The pooled money/men's control allocative system is the opposite of the pooled money/women's control allocative system. Under this system all money is combined into a single account or pot that is controlled by the husband. ${ }^{44}$ Research suggests this system is associated with higher income levels where only the man is employed. ${ }^{45}$

6. Pooled Money/Equal Control.-The final allocative system, pooled money/equal control, is one in which the spouses combine all of their funds into a joint account or pool and then share management responsibility equally. ${ }^{46}$

\section{B. The Best Approach: Pooled Money/Equal Control}

Research suggests that a couple's choice of allocative system impacts the quality and stability of their relationship, the wellbeing of their children, and women's position in the economy and society as a whole. ${ }^{47}$ The bulk of the research demonstrates that shared management and access to pooled financial assets by both spouses is a desirable outcome. In contrast, "if one person manages financial assets, whether it is the woman or the man, women are in a disadvantaged position." 48

1. Significance of Equality Within the Relationship.-Shared power is a critical factor in intimate relationships. ${ }^{49}$ Research shows that "individuals in

39. See id.
40. Id.
41. Id.
42. Id. at 361.
43. Id.
44. Id.
45. Id.
46. Id.
47. Id.
48. Yodanis \& Lauer, supra note 24, at 1308.
49. See, e.g., Hara Estroff Marano, Love and Power, PsYCHOL. TODAY (Apr. 24, 2014), 
intimate relationships are concerned about equity, that the presence or absence of equity has significant effects on individuals' satisfaction, and that equitable relationships are more stable than inequitable relationships." ${ }^{50}$ Put simply, shared power is often the key to successful intimate relationships. ${ }^{51}$ Yet, equality is elusive for many couples. "The social context both supports and inhibits the development of marital equality." ${ }^{, 3}$ Changing societal views of gender roles supports a move towards equality and couples tend to "enter into relationships with egalitarian ideals." ${ }^{4}$ However, "the power differential between men and women in the larger social context ... spills into marriages." in financial decisions are particularly problematic. ${ }^{56}$ If a couple, like many couples, chooses an inequitable allocative system then their relationship faces an uphill battle. ${ }^{57}$ Disagreements about money are more likely to be high-conflict in nature than other types of disagreements, and, consequently, are strong predictors of divorce. ${ }^{58}$ In addition to the problems directly linked to a couples' financial power disparity, a couple's choice of allocative system is often associated with other measures of inequality in the relationship. ${ }^{59}$ Inequitable allocative systems are ubiquitous in abusive relationships. ${ }^{60}$

2. Significance of Equality to Children and Family Unit. - Research suggests that children's and women's wellbeing are positively impacted by the wife's equal access to all of a couple's money. ${ }^{61}$ Jan Paul's research from the United Kingdom demonstrates that spending is a gendered activity. ${ }^{62}$ Women are more likely than men to spend money on resources that will benefit the family and children - a pattern confirmed in other studies ${ }^{63}$ — while men spend more money

https://www.psychologytoday.com/articles/201312/love-and-power, archived at http://perma.cc/ 28K5-ZQP8; Peter Kollock et al., The Judgment of Equity in Intimate Relationships, 57 SoC. PSYCHOL. Q., 340, 340-41 (1994).

50. Kollock et al., supra note 49, at 340-41.

51. See Marano, supra note 49.

52. Carmen Knudson-Martin \& Ann Rankin Mahoney, Language and Processes in the Construction of Equality in New Marriages, 47 FAM. RELATIONS 81, 82 (1998).

53. Id.

54. Id.

55. Id.

56. See Dew, supra note 6 .

57. $I d$.

58. Id. at 624 .

59. Vogler, supra note 33, at 461.

60. See Yodanis \& Laurer, supra note 24, at 1307.

61. See, e.g., Nancy Burns et al., The Public Consequences of Private Inequality: Family Life and Citizen Participation, 91 AM. Pol. SCI. REV.373, 377 (1997); C. Nyman, Gender Equality in "The Most Equal Country in the World"? Money and Marriage in Sweden, 47 Soc. REV. 767 (1999).

62. Jan Pahl, The Gendering of Spending Within Households, RADICAL STATS. 75, 38-48 (2000).

63. See Burns et al., supra note 61. 
on pleasure and discretionary items. ${ }^{64}$ The numbers are striking. In Pahl's study, women were responsible for nearly all expenditures on women's and children's clothing: $90 \%$ and $85 \%$, respectively. ${ }^{65}$ Women accounted for $80 \%$ of food expenditures, $78 \%$ of child-care and school related expenditures, and $59 \%$ of medical and dental expenditures. ${ }^{66}$ Men, in contrast, accounted for $73 \%$ of alcohol expenditures, $69 \%$ of motor vehicle expenditures, $64 \%$ of vacation expenditures, and $65 \%$ of gambling expenditures.$^{67}$ Catherine Kenney's research in the United States on children's food insecurity echoes these findings. ${ }^{68} \mathrm{Her}$ research shows a relationship between a couple's choice of allocative system and food insecurity. ${ }^{69}$ The relationship between food security and poverty is not entirely obvious. "About $36 \%$ of U.S. households below the poverty line experience food insecurity, but even above $185 \%$ of the poverty line, $7 \%$ of U.S. households with children are food insecure, suggesting that parents' capabilities, preferences, and circumstances may also play a role." ${ }^{70}$ The choice of allocative system a couple uses is correlated with the likelihood their children will experience food insecurity. ${ }^{71}$ Generally, the more power the father has over the family's income the more likely the children will experience food insecurity. ${ }^{72}$ "The odds of child food insecurity are over 2.5 times higher when the father controls pooled income than when the mother does."73 Interestingly, spousal equality did not improve things. "The odds of food insecurity are almost 2.3 times higher when both parents 'equally' control pooled income than when the mother alone does." "74 This phenomenon is likely a result of "gender inequalities in control of decision making [that] remain under the surface of these nominally equal accounts." ${ }^{, 75}$

3. Significance of Equality to Society.-A couple's allocative system may seem like a purely private matter. The truth, however, is that inequitable allocative systems harm society as whole. Cross-national research has shown a direct correlation between income inequality at the national level and the prevalence of unequal spousal allocative systems. ${ }^{76}$ Some sociologists theorize

\section{4. $I d$.}

65. Id.

66. Pahl, supra note 62.

67. Id.

68. Catherine T. Kenney, Father Doesn't Know Best? Parents' Control of Money and Children's Food Insecurity, 70 J. MARRIAGE \& FAM. 654 (2008).

69. Id.

70. Id. at 657 (citations omitted).

71. Id. at 663 .

72. See id. at 666-67 ("Children are more likely to be food insecure when their father controls either pooled or separate income than when their mother controls pooled income.”).

73. Id. at 663 .

74. $I d$.

75. Id. at 667.

76. See Sean R. Lauer \& Carrie Yodanis, Economic Inequality In and Outside of Marriage: Individual Resources and Institutional Context, 23 EUR. SoC. REV. 573, 579 (2007). 
that spouses may adopt allocative systems in light of the societies in which they reside. ${ }^{77}$ "For example, couples in context where economic inequality is pervasive and accepted may be more likely to draw on these institutionalized rules and practices and adopt them within their own relationships." ${ }^{178}$ The reverse of this theory is probably true as well. "[P] atriarchal domestic relationships have consequences for women's ability to participate fully as citizens."

Men are more politically active than women from a financial standpointmaking more and larger contributions to political causes.$^{80}$ A 1997 study found an interesting relationship between this phenomenon and domestic life. ${ }^{81}$ Husbands who reported greater authority at home - particularly with respect to financial decisions-were more likely to be active in politics. ${ }^{82}$ A husband's power over financial decisions at home appeared to increase his political activity "beyond what would be expected on the basis of [his] other characteristics." 83

\section{Legal Regulation of Allocative Systems}

A couple's ability to select a particular allocative system is impacted, to some extent, by the laws regulating the management of property. Two marital property regimes exist in the United States: the separate property system and the community property system. ${ }^{84}$ The separate property system, founded in common law, employs a title theory to the ownership of marital property. ${ }^{85}$ During marriage, the spouse who holds the title to an asset has the ownership of that asset and the authority to manage it. ${ }^{86}$ The community property system, in contrast, is founded in civil law and provides for an automatic sharing of all marital property by the spouses. ${ }^{87}$ Each spouse has an equal present and vested ownership interest in each item of marital property. For nearly a century, scholars widely regarded American community property laws as progressive and beneficial to

77. See id. at 575 .

78. Id. at 579 .

79. Burns et al., supra note 61 , at 373 .

80. Id. at 374; see also Sarah Bryner \& Doug Weber, Sex, Money \& Politics, CTR. FOR RESPONSIVE POLITICS (Sept. 26, 2013), available at http:// http://www.opensecrets.org/news/ reports/gender.php, archived at http://perma.cc/VX3Z-AZLS.

81. Burns et al., supra note 61 , at 373 .

82. Id. at 382 .

83. Id. at 384 .

84. See Friedrich K. Juenger, Marital Property and the Conflict of Laws: A Tale of Two Countries, 81 Colum. L. REV. 1061, 1067 (1981).

85. See Laura W. Morgan \& Edward S. Snyder, When Title Matters: Transmutation and the Joint Title Gift Presumption, 18 J. AM. ACAD. MATRIM. LAW 335, 336-38 (2003) (discussing the title system).

86. Id.

87. Caroline Bermeo Newcombe, The Origin and Civil Law Foundation of the Community Property System, Why California Adopted it, and Why Community Property Principles Benefit Women, 11 U. MD. L. J. RACE, Religion, Gender \& Class 1, 7 (2011). 
women ${ }^{88}$ - calling these laws the "crowning point of women's legal emancipation." $" 89$ Wives in community property jurisdictions enjoyed-at least in theory - an elevated status compared to their counterparts in common law states because they possessed a current property interest in their husbands' earnings. ${ }^{90}$ Historically, both systems, in their application, reinforced a preference for male-dominated allocative systems and served to perpetuate the money-power gap faced by women.

\section{A. Separate Property System}

The separate property system, based in common law, historically adopted the "merger" theory of marriage. ${ }^{91}$ Under this view, marriage resulted in the legal merger of the husband and wife into a single individual under the law. ${ }^{92}$ This suspension or merger of the wife's separate legal identity — called coverture-had a number of legal effects. ${ }^{93}$ Married women could not sue or be sued, enter into or be held liable for contracts, incur debts, or manage property. ${ }^{94}$ While a woman was under coverture she lost the authority to manage even the property she brought into the marriage and her own earnings during marriage. ${ }^{95}$ These management rights, rather, belonged to the husband. ${ }^{96}$

Beginning in the 1800 s the separate property jurisdictions enacted a series of laws - the Married Women's Property Acts - which sought to remove the legal disabilities of married women. ${ }^{97}$ These acts remain the only significant change in the law in separate property states with respect to the management of marital property during marriage. ${ }^{98}$ The Married Women's Property Acts were "designed to abolish the common law 'unity' of husband and wife, and thereby to secure to a married woman a separate legal identity from her husband with corresponding substantive and procedural rights." 99 Since the enactment of the Married Women's Property Acts, management of property by spouses in separate property

88. See M.R. Kirkwood, Historical Background and Objectives of the Law of Community Property in the Pacific Coast States, 11 WASH. L. REV. 1, 11 (1936).

89. Alice L. Bendheim, Comment, Community Property: Male Management and Women's Rights, 1972 LAW \& SOC. ORDER 163, 163.

90. See generally Newcombe, supra note 87 , at 1.

91. Hack v. Hack, 433 A.2d 859, 861 (Pa. 1981).

92. Id.

93. Id.

94. Id.

95. Bernie D. Jones, Revisiting the Married Women's Property Acts: Recapturing Protection in the Face of Equality, 22 AM. U. J. GENDER SOC. POL'Y \& L 91, 99 (2013).

96. Id.

97. See, e.g., Bloomfield v. Brown, 25 A. 2d 354, 369 (R.I. 1942) ("It may be said generally that the effect of the married women's act is to raise up the wife, in the eyes of the law, to the same position as that of the husband.").

98. See generally Jones, supra note 95.

99. Hack, 433 A.2d at 861. 
jurisdictions is determined by reference to the title to the property. ${ }^{100}$ A spouse who takes property in his or her own name individually may freely manage that property without the involvement of the other spouse. ${ }^{101}$ If the spouses elect to take title to property as joint tenants, then joinder or concurrence of the other spouse may be required. ${ }^{102}$ Separate property jurisdictions do not, however, generally require that spouses jointly own marital property. ${ }^{103}$ Rather, spouses must take some affirmative step to cause title to property to be in both of their names. ${ }^{104}$ The fact that separate property states do not contemplate the automatic concurrent ownership of property during marriage is, probably, the single most distinguishing feature of the two systems today.

\section{B. Community Property System}

The American community property jurisdictions ${ }^{105}$ - with the exception of Wisconsin ${ }^{106}$ - generally trace their lineage to their Spanish, and to a more limited extent, French roots. ${ }^{107}$ The states adhered to a ganancial system of community property, which draws a distinction between so-called community assets and separate assets based on the timing and source of their acquisition. ${ }^{108}$ Generally, assets acquired before marriage, or by gift or inheritance, remained a spouse's separate property. ${ }^{109}$ Assets acquired during marriage as a result of a spouse's labor or industry - most notably earnings from employment - were generally community property. ${ }^{110}$ Community assets were owned equally by both

100. Id.

101. Id.

102. J. Thomas Oldham, Management of the Community Estate During an Intact Marriage, 56 LAW \& CONTEMP. PROBS. 99-170 (Spring 1993), available at http://scholarship.law. duke.edu/lcp/vol56/iss2/4, archived at http://perma.cc/VCM8-WDB8.

103. Id.

104. Id.

105. Arizona, California, Idaho, Louisiana, Nevada, New Mexico, Texas, Washington. Howard S. Erlanger \& June M. Weisberger, From Common Law Property to Community Property: Wisconsin's Marital Property Act Four Years Later, 1990 WIS. L. REV. 769, 769 n.2.

106. Wisconsin became a community property state on January 1, 1986. Because Wisconsin was not a part of the managerial reform movement it is largely omitted from this Article. See generally id.

107. See, e.g., Harriet S. Daggett, The Modern Problem of the Nature of the Wife's Interest in Community Property - A Comparative Study, 19 CAL. L. REV. 567, 569-70 (1931).

108. See William A. Reppy, Jr., Major Events in the Evolution of American Community Property Law and Their Import to Equitable Distribution States, 23 FAM. L.Q. 163, 166 (1989).

109. See, e.g., ARIZ. REv. Stat. AnN. § 2173 (1928); CAL. Civ. CodE $§ \S 162-64$ (West 1892); IdAHO CODE ANN. §§4051-52 (West 1901); LA. Civ. CODE ANN. art. 2334 (1880); NEV. REV. STAt. $\S 510$ (1900).

110. See, e.g., ARIZ. Rev. Stat. ANn. §2172 (1928); CAL. Civ. CODE $\S ~ 162-64$ (West 1892); IDAHO CODE ANN. § 2053 (West 1901); NEV. REV. StAT. § 511 (1900). 
spouses. ${ }^{111}$ These basic similarities in the classification of assets continue today.

The community property states agreed on the superiority of male management of the community assets. ${ }^{12}$ To that end, the husband was legally the sole manager of the community property in every community property state. ${ }^{113}$ A number of states went further and granted the husband management power over his wife's separate property as well - effectively depriving married women of any opportunity to manage or control property. ${ }^{114}$ From the wife's point of view, the community property states offered few advantages over the separate property states during an ongoing marriage. The most meaningful advantage was not obtained unless a wife divorced or outlived her husband. ${ }^{115}$ In the community property states wives were better off in these events because they would be entitled to one-half of the former community property whereas wives in common law states usually had no property rights. ${ }^{116}$

In the early years, the husband's power over the community property was incredibly broad. Two articles from the California Civil Code of 1892 are typical and illustrate this point:

$\S 156$. The husband is the head of the family. He may choose any reasonable place or mode of living, and the wife must conform thereto.

...

$\S 172$. The husband has the management and control of the community property, with the absolute power of disposition (other than testamentary) as he has of his separate estate. ${ }^{117}$

As a tradeoff for his vast management rights, however, the husband was held to a type of fiduciary standard in managing the community property. ${ }^{118}$ California

111. See $\S 2172 ; \S 162-64 ; \S 2053 ; \S 511$.

112. See Daggett, supra note 107 , at 577-78 (explaining the husband had only one restriction on the disposition of community property).

113. Erlanger \& Weisberger, supra note 105, at 773.

114. See, e.g., IDAHO CODE ANN. § 2054 (West 1887) ("The husband has the management and control of the separate property of the wife. ...”); LA. CIV. CODE ANN. arts. 2350, 2384, 2390 (1880) (granting the wife limited management rights over her paraphernal property but not property considered part of her dowry); TEX. CIV. REV. STAT. art. 4621 (West 1913) (“All property, both real and personal, of the wife, owned of claimed by her before marriage . . . shall be the separate property of the wife; but during the marriage the husband shall have the sole management of all such property."). But see, e.g., CAL. CIV. CODE $§ 162$ (West 1892) ("The wife may, without the consent of her husband, convey her separate property.”); NEV. REV. STAT. § 518 (1911) (“The wife may, without the consent of her husband, convey, charge, incumber, or otherwise in any matter dispose of her separate property."); WASH. REV. CODE $§ 5916$ (1910) (allowing a married woman to "manage, lease, sell, convey, encumber, or devise by will" her separate property).

115. Reppy, supra note 108 , at 164.

116. $I d$.

117. CAL. CIV. CodE $\S \S 156,172$ (West 1892).

118. Vai v. Bank of Am. Nat'l Trust \& Savings Ass'n, 56 Cal. 2d 329, 377 (1961). Accord Fields v. Michael, 205 P. 2d 402, 405-06 (Cal. Dist. Ct. App. 1949); Jorgensen v. Jorgensen, 193 
equated the husband to a trustee reasoning that "[b]ecause of his management and control over the community property, the husband occupies the position of trustee for his wife in respect to her one-half interest in the community assets." 119 New Mexico cases, calling the husband a "sort of fiduciary" held "[ $t]$ he husband being the manager of the community property should exercise the highest good faith toward the community interests." 120 Nevada courts likened the spousal relationship to a business relationship holding that the husband's "position is that of a trustee for the wife's share analogous to the trustee relationship of a partner to his partnership or an agent to his principal." 121 Idaho and Louisiana took similar approaches. ${ }^{122}$ Texas cases held that "a husband is in a restricted sense the trustee for his wife, bound to good faith, and derelict in duty if he conceals knowledge from her necessary to enable her to protect her rights, and that withholding needed information from her is a breach of duty constituting fraud." 223 From a practical standpoint, however, the wife could generally do little to hold her husband accountable for a breach of his fiduciary duty unless the couple had already separated. ${ }^{124}$ Only then could the wife seek an accounting from the husband or seek relief for mismanagement, fraud, or concealment of the community property. ${ }^{125}$

As an extension of the husband's position as a fiduciary, states restricted his ability to dispose of community property gratuitously to the detriment of his wife. ${ }^{126}$ California statutory law prevented the husband from making gifts of community property or selling community property for insufficient consideration without the wife's written consent. ${ }^{127}$ Louisiana restricted the husband's ability to make a gift of community real estate unless it was for the benefit of the couple's children. ${ }^{128}$ Texas cases prevented the husband from donating

P. 2d 728, 733 (Cal. 1948).

119. See Vai, 56 Cal. 2d at 377. Accord Fields, 205 P. 2 d at 405-06; Jorgensen, P. $2 d$ at 733.

120. Laughlin v. Laughlin, 155 P.2d 1010, 1019 (N.M. 1944). Accord Terry v. Humphries, 203 P. 539, 541 (N.M. 1922).

121. Fox v. Fox, 401 P. 2d 53, 57 (Nev. 1965).

122. See Sande v. Sande, 360 P. 2d 998, 1001 (Idaho 1961); Hodson v. Hodson, 292 So. 2d 831, 836-37 (La. Ct. App. 1974); Pitre v. Pitre, 172 So. 2d 693, 695 (La. 1965).

123. Swearingen v. Swearingen, 193 S.W. 442, 452 (Tex. Civ. App. 1917).

124. See Flores v. Arroyo, 56 Cal. 2d 492, 494-95 (Cal. 1961) ("It is part of a husband's fiduciary duties to account to the wife for the community property when the spouses are negotiating a property settlement ...."); Ramseyer v. Ramseyer, 558 P. 2d 76, 80 (Idaho 1976) ("[T]he husband, as the manager of the community under the law at the time the divorce was granted, owed a fiduciary duty to the wife to account for the community property."); Mazour v. Mazour, 180 P. 2d 103, 104-05 (Nev. 1947).

125. See id.

126. See, e.g., CAL. CIV. CODE $§ 172$ (1909).

127. Id.; see, e.g., Novo v. Hotel Del Rio, 295 P. 2 d 576 (Cal. Dist. Ct. App. 1956) (holding that transfer of community funds to satisfy gambling debt without wife's written concurrence fell within the scope of the statute).

128. LA. Civ. Code ANN. art. 2404 (1880). 
community property in fraud of the wife's rights. ${ }^{129}$ Washington case law held that the "husband is given management and control of community personal property for the purpose of facilitating the business of the community." ${ }^{130}$ In practice, Washington courts used this standard to invalidate a variety of irresponsible gratuitous transfers of community property by the husband. ${ }^{131}$ Over time, the community property states began imposing more meaningful limitations to the husband's control by granting the wife a certain measure of veto power over important transactions. ${ }^{132}$ This typically meant the wife was afforded some veto power in transactions involving community real estate or immovable property. ${ }^{133}$ Community property states also enacted measures aimed at ensuring the wife had some access to the bare necessities of life. By the early 1900s, California law provided that "no sale, conveyance or encumbrance of the furniture, furnishings and fittings of the home, or of the clothing and wearingapparel of the wife or minor children, which is community property, shall be made without the consent of the wife." ${ }^{134}$ A number of states adopted some form of the "necessaries doctrine" which allowed the wife to enter contracts in order to obtain food, clothing, and other basic necessities. ${ }^{135}$

Eventually, women in some community property states obtained independent management authority over their earnings. ${ }^{136}$ Without specific legislation allowing a wife to manage her earnings she was not allowed to even deposit or spend her own paycheck. ${ }^{137}$ Texas granted married women management power over their personal earnings in 1913. ${ }^{138}$ Unfortunately, subsequent legislative revisions muddied the issue by omitting the language granting the wife management of her personal earnings and earnings from her separate

129. See, e.g., Watson v. Harris, 130 S.W. 237, 241 (Tex. Civ. App. 1910); Martin v. Moran, 32 S.W. 904, 905-06 (Tex. Civ. App. 1895).

130. Hanley v. Most, 115 P. 2d 933, 945 (Wash. 1941).

131. See id. at 944-45.

132. Andrea Carroll \& Richard D. Moreno, 16 La. Civ. LaW Treatise: Matrimonial REGIMES $\S 5.1$ (2014).

133. See, e.g., ARIZ. REv. StAT. ANN. § 32:3850 (1913) (requiring the joinder of both spouses in real estate transactions); IDAHO CODE ANN. § 2061 (West 1901) (joinder requirement for homestead); NeV. ReV. STAT. § 515 (1911) (joinder requirement for homestead); Harry M. Cross, The Community Property Law in Washington, 15 LA. L. REV. 640, 642-43 (1955) (discussing Washington's joinder requirement for real estate transactions).

134. CAL. CIV. CODE $§ 172$ (West 1909).

135. See, e.g., Durwood Douglas Crawford, Comment, Legal Rights of Married Women in Texas, 13 Sw. L.J. 84, 84 (1959); Joseph W. McKnight, Texas Community Property Law: Conservative Attitudes, Reluctant Change, 56 LAW \& CONTEMP. Probs. 71, 76 (1993).

136. See, e.g., D. F. Bobbitt, Contractual Power of Married Women in Texas, 1 TEX. L. REV. 281, 283-84 (1923); Jo Carrillo, The M Word: From Partial Coverture to Skills-Based Fiduciary Duties in Marriage, 22 Hastings WoMEN's L.J. 257, 261 (2011).

137. See, e.g., Crawford, supra note 135, at 84-85; McKnight, supra note 135, at 76.

138. See Robert Blevins, Jr., Recent Statutory Changes in the Wife's Managerial Powers, 38 TEX. L. REV. 55, 75 (1959); Bobbitt, supra note 136, at 283-84. 
property - both considered community property in Texas - and several courts took the ambiguity as an opportunity to once again divest married women of control over their earnings. ${ }^{139}$ The issue was not laid to rest until $1967 .{ }^{140}$ California granted women management powers over their own earnings in 1951. ${ }^{141}$ In order to exercise this right, however, the wife had to open and maintain a separate bank account in her own name. ${ }^{142}$ Commingled funds fell back under the husband's control. ${ }^{143}$ As discussed in Part IV, the explicitly male preference was not completely abandoned until 1980.

\section{Allocative Systems in Practice-Pre-Reform}

Unfortunately, researchers only recently began to examine the allocation of money within households. ${ }^{144}$ Information for the pre-reform (pre-1970s) era is sparse and relies heavily on anecdotal evidence. ${ }^{145}$ This evidence is, however, informative. As the law suggested, management of financial matters was gendered in practice. ${ }^{146}$ Among wealthier couples, the separate money/men's control allocative system was common. ${ }^{147}$ Wealthier women might receive some funds from their husbands in order to manage household expenses, but real financial power rested with the husband. ${ }^{148}$ Upper and middle class women who wanted some cash of their own had to negotiate with their husbands or employ other rather creative techniques for obtaining their own money. ${ }^{149}$ Anecdotally, wealthy women were relegated to deceitful and demoralizing tactics in order to obtain some cash of their own: women asked, begged, and withheld sex from their husbands in an effort to gain some cash of their own. ${ }^{150}$ If they could not get enough cash from their husbands directly, wealthy wives got even more creative. ${ }^{151}$ Some women tried to set aside and save some of the money their

139. See Pottorf v. J.D. Adams Co., 70 S.W.2d 745 (Tex. App. 1934); Blevins, supra note 137, at $75-78$.

140. See William O. Huie, Divided Management of Community Property in Texas, 5 TeX. TECH L. REV. 623, 625 (1974).

141. See Carrillo, supra note 136, at261; William Q. De Funiak, Community Property, 4 ANN. SuRV. CAL. L. 139, 139 (1952); Madeleine Radensky, Note, Giving the "Little Woman" Equal Management and Control, 2 W. ST. U. L. REV. 180, 184-85 (1974).

142. Carrillo, supra note 136, at 261.

143. Id.

144. See Viviana A. Zelizer, The Social Meaning of Money: "Special Monies," 95 AM. J. Soc. 342, 342-343 (1989).

145. See id. at 352-53.

146. Id. at 354-55.

147. Id.

148. Id. at 355 .

149. Id. at 357 .

150. Id. at 357-58.

151. Id. 
husbands gave them for housekeeping expenses. ${ }^{152}$ Those who could not employ these creative techniques, however, relied on credit lines established by their husbands to buy household goods. ${ }^{153}$ Paradoxically, wealthy husbands would gladly pay the large credit bills their wives ran up, but were "unwilling to trust them with the smallest amount of ready money."154 "Women bargained with dressmakers, milliners, and shopkeepers to add extra items to their bills so that, when the bill was paid, the rich man's wife may get a rake-off and possess a few dollars." 155 Some wealthy women sold their old furniture to their servants to raise cash. ${ }^{156}$ Wives even stole money from their husband's pockets while they were asleep at night. ${ }^{157}$

The situation for lower-class women was different, but not better. Workingclass families tended to employ the separate money/women's control allocative system. ${ }^{158}$ Working husbands and children would hand over their pay-or at least a portion of their pay - to the wife on payday so that she could pool the money and apply it towards the family's expenses. ${ }^{159}$ The husbands and children typically received an allowance from their earnings for their own personal spending money. ${ }^{160}$ This allocative system essentially ignored the legally sanctioned management regime and, to some observers, working-class wives appeared to have more financial authority and freedom than their wealthier counterparts. It seems unlikely, however, that lower class men were simply more comfortable with female financial empowerment than wealthy men. The more probable explanation for the gender reversal is that managing the finances in a working-class family was a difficult and laborious task rather than a source of empowerment. ${ }^{161}$ The working-class family needed the bulk of its income to pay for basic living expenses. ${ }^{162}$ Wives were left with the unpleasant task of trying to make ends meet while husbands, and sometimes children, retained an allowance for their own discretionary spending. ${ }^{163}$ Wives, in contrast, were rarely left with any discretionary funds of their own. ${ }^{164}$ Furthermore, the husbands made the initial determination of just how much of their earnings they were willing to hand over to their wives each week. ${ }^{165}$ In many cases, it seems, wives did not

152. $I d$.

153. Id

154. Id. at 359 (internal quotation marks omitted).

155. Id. at 358 (internal quotation marks omitted).

156. Id.

157. $I d$.

158. Id. at 355 .

159. Id.

160. Id.

161. Id. at 363.

162. Id. at 363-64.

163. Id.

164. Id.

165. Id. 
even know how much money their husbands actually made. ${ }^{166}$

Would legal reforms change the gendered treatment of money?

\section{THE REFORM MOVEMENT: AN "ERA” OF CHANGE}

The continued growth of the married woman's economic power should have corresponded with a move towards widespread egalitarian allocative systems within marriage. It did not. As Table 1 demonstrates, the percentage of women, and married women in particular, that worked outside the home began to increase dramatically in the middle of the twentieth century, eventually tapering off in the 1990s. ${ }^{167}$

Table 1: Women in the Workforce By Year ${ }^{168}$

\begin{tabular}{|c|c|c|}
\hline Year & $\begin{array}{l}\text { Percentage of all } \\
\text { Women who Worked }\end{array}$ & $\begin{array}{l}\text { Percentage of Working } \\
\text { Women who were } \\
\text { Married }\end{array}$ \\
\hline 1890 & 18.9 & 4.6 \\
\hline 1900 & 20.6 & 5.6 \\
\hline 1910 & 25.4 & 10.7 \\
\hline 1920 & 23.7 & 9.0 \\
\hline 1930 & 24.8 & 11.7 \\
\hline 1940 & 25.8 & 15.6 \\
\hline 1950 & 29.0 & 23.0 \\
\hline 1960 & 34.5 & 31.7 \\
\hline 1970 & 43.3 & 40.5 \\
\hline 1980 & 51.5 & 49.8 \\
\hline 1990 & 57.5 & 58.4 \\
\hline 2000 & 59.9 & 61.1 \\
\hline 2010 & 58.6 & 61.0 \\
\hline
\end{tabular}

The 1960s and 1970s marked an era of significant legal and economic gains for women. ${ }^{169}$ Reforms in divorce laws sought to place women on fair legal and economic footing with their former husbands and to reflect an egalitarian view of marriage and gender. ${ }^{170}$ Nearly every state adopted some form of no-fault divorce, which allowed spouses to divorce without proving the guilt or innocence

166. Id.

167. See supra Table 1.

168. Bureau of the Census, Historical Statistics of the United States, Colonial TIMES TO 1970, 133-34 (1975), available at https://fraser.stlouisfed.org/docs/publications/ histstatus/hstat1970_cen_1975_v1.pdf, archived at http://perma.cc/D6GB-GJPX; U.S. CENSUS Bureau, Statistical AbStract of the United States: 2012, 384 (2012), available at http://www.census.gov/prod/2011 pubs/12statab/labor.pdf, archived at http://perma.cc/3L4D-AN26.

169. See, e.g., Carol S. Bruch, Of Work, Family Wealth, and Equality, 17 FAM. L.Q. 99, 99100 (1983).

170. Id. 
of either spouse in the breakdown of the relationship. ${ }^{171}$ Fault also became irrelevant for determining issues of property division and child custody. ${ }^{172}$

Changes in property division laws and alimony laws further sought to put women on equal footing with men. Historically, alimony had only been available to the wife and often depended on her being found free from fault. ${ }^{173}$ The new alimony laws "emphasize[d] economic need and the desirability of terminating the former spouses" contact with one another" 174 and favored "short rehabilitive awards" over lifetime awards. ${ }^{175}$ Rather than using alimony as a tool to punish the guilty spouse, courts began to view alimony as a "method for rehabilitating the party disadvantaged by the divorce," which was typically the woman. ${ }^{176}$

The common law states, undoubtedly influenced by the community property states, adopted an equitable distribution approach to dividing assets at divorce. ${ }^{177}$ At divorce, courts traditionally awarded each spouse the property that was titled in his or her name - an approach that almost always favored the husband and left the wife at a distinct economic disadvantage. ${ }^{178}$ Equitable distribution, in contrast, allowed the courts to divide the assets acquired during the marriage without regard to title. ${ }^{179}$ "[T] distribution of property reflect[ed] the notion that marriage is an egalitarian partnership with each spouse's efforts benefitting the whole." 180

In the decades since these changes to the divorce laws, numerous scholars and researchers have seriously questioned whether the changes actually improved the status of women post-divorce. ${ }^{181}$ Even if these changes did improve the status of women post-divorce, they did not address the status of women during marriage. Giving a woman an equitable share of her husband's assets at divorce simply did not address the economic inequality that occurs during an intact marriage. The community property states, however, were forced to address that

171. See, e.g., id. at 99-100; Marjorie E. Kornhauser, Theory Versus Reality: The Partnership Model of Marriage in Family and Income Tax Law, 69 TEMP. L. REV. 1413, 1417 (1996).

172. See Herma Hill Kay, Equality and Difference: A Perspective on No-Fault Divorce and its Aftermath, 56 U. CIN. L. REV. 1, 36-37 (1987).

173. See Nora J. Lauerman, A Step Toward Enhancing Equality, Choice, and Opportunity to Develop in Marriage and at Divorce, 56 U. CIN. L. REV. 493, 498-99 (1987).

174. Bruch, supra note 169 , at 100.

175. Kornhauser, supra 171 , at 1417.

176. Williams v. Williams, 302 N.W.2d 754, 758 (N.D. 1981).

177. See, e.g., Marsha Garrison, Good Intentions Gone Awry: The Impact of New York's Equitable Distribution Law on Divorce Outcomes, 57 BROOK. L. REV. 621, 628-30 (1991)

178. See, e.g., Brooke Grossman, Note, The Evolution of Equitable Distribution in New York, 62 N.Y.U. ANN. SURV. AM. L. 607, 609 (2007).

179. Garrison, supra note 177 , at 628.

180. Lauerman, supra note 173 , at 501.

181. See, e.g., Garrison, supra note 177, at 632-36; Kay, supra note 172, at 1-4; Lynn D. Wardle, No-Fault Divorce and the Divorce Conundrum, 1991 BYU L. REV. 79, 79 (1991); Martin Zelder, The Economic Analysis of the Effect of No-Fault Divorce Law on the Divorce Rate, 16 HARV. J.L. \& PUB. POL'Y 241, 241-243 (1993). 
precise issue.

The potential passage of the Equal Rights Amendment and the evolving constitutional equal protection jurisprudence during this same time period forced the American community property jurisdictions to enact changes that did affect the economic relationship of spouses during intact marriages. ${ }^{182}$ Community property states abandoned their old head and master laws in favor of genderneutral property management systems. ${ }^{183}$ The community property states had the opportunity to do something truly radical - to cause egalitarian allocative systems to become the law of the land. Reformers were certainly aware of this possibility and a few of them tried to use the law as an instrument of change and to close the gendered money-power gap. ${ }^{184}$

By the end of the reform era all of the community property jurisdictions had abandoned their gender-based management regime in favor of a gender-neutral approach. ${ }^{185}$ But did they achieve equality? No.

A wife in an intact marriage in a community property state is in no better position today than is a wife in a common law state. As in the past, the real "benefits" of community property will only be realized if the wife divorces her husband or outlives him - and reforms in common law states have since lessened the disparities between the systems in the death and divorce context.

\section{A. Equality Was Not Achieved: Quantitative \& Qualitative Research}

Equality was not achieved. Money management remains a highly gendered activity — one that typically operates to the disadvantage of the wife. ${ }^{186}$ Although no state-specific studies exist, a number of studies shed light on how married couples actually manage their finances. ${ }^{187}$ The existing research demonstrates that the pooled money/equal control allocative system - the system widely regarded as the most desirable system - is not the approach utilized by most couples. ${ }^{188}$

Several studies demonstrate that married American couples prefer to pool their income in some manner. ${ }^{189}$ One study, relying on data from the initial wave of the 1984 panel of the Survey of Income and Program Participation ("SIPP") conducted by the U.S. Bureau of the Census, examined how couples managed their money by looking at their bank accounts. ${ }^{190}$ Only $18 \%$ of couples reported

182. See, e.g., Morgan A. Jones, History of the Family Code, 5 TEX. TECH L. REV. 267, 267 (1973).

183. See Lauerman, supra note 173, at 501.

184. See Bruch, supra note 169, at 99-101.

185. See Wardle, supra note 181 , at 79.

186. See, e.g., Zelizer, supra note 144 , at 368-70.

187. See Judith Treas, Money in the Bank: Transaction Costs and the Economic Organization of Marriage, 58 AM. Soc. REV. 723, 727 (1993).

188. See, e.g., id.

189. Id.

190. Id. 
using exclusively separate bank accounts - a possible indicator that these couples did not pool their income. ${ }^{191}$ Approximately $18 \%$ of couples maintained both joint and separate bank accounts. ${ }^{192}$ The remaining approximately $64 \%$ of respondents maintained only joint bank accounts. ${ }^{193}$ On the whole, most respondents $(82 \%)$ pooled their income in some fashion, but the study did not reveal whether that pooling also resulted in equal control. ${ }^{194}$ Another study, relying on data from the 1994 Family and Changing Gender Roles II module of the International Social Survey Program ("ISSP"), had similar findings using a different data set. ${ }^{195}$ This study found that approximately $83 \%$ of American married couples pooled their income together, while approximately $17 \%$ of married couples kept their money separate. ${ }^{196}$ Again, the study did not examine how money was managed within the pooled system. ${ }^{197}$ More recent surveys indicate that couples increasingly maintain a mixture of joint and separate bank accounts. ${ }^{198}$ A 2014 survey conducted by TD Bank found that $42 \%$ of couples that maintain joint bank accounts also maintain separate accounts. ${ }^{199}$

Several studies suggest that truly equal management of pooled income is not common. ${ }^{200}$ Qualitative studies have found that "among male breadwinnerfemale homemaker couples using joint accounts, inequalities remain in access to money because nonearning women feel uncomfortable spending on themselves using money they did not earn or because breadwinning men retain primary decision-making power over money that is nominally pooled."201 A 1997 study based on data collected by telephone interviews found that, although wives are primarily responsible for shopping and paying the bills, "financial decision making is a domain in which husbands report, on average, that they exercise greater control than is reported by wives." ${ }^{202}$ Nearly three-fourths of the husbands surveyed reported that they were responsible for making major financial decisions. ${ }^{203}$ Yet, the same survey showed a widespread belief in gender equality

191. Id. at 729 .

192. Id.

193. Id.

194. Id. at 729 .

195. Kristen R. Heimdal \& Sharon K. Houseknecht, Cohabiting and Married Couples' Income Organization: Approaches in Sweden and the United States, 65 J. MARRIAGE \& FAM. 525, 525-32 (2003).

196. Id. at 532 .

197. Id.

198. Press Release, TD Bank, TD Bank Survey Finds Many Couples Maintain Separate Bank Accounts (March 24, 2014), available at https://mediaroom.tdbank.com/2014-03-24-TD-BankSurvey-Finds-Many-Couples-Maintain-Separate-Bank-Accounts, archived at http://perma.cc/ AEA7-AV6A.

199. Id.

200. Kenney, supra note 1, at 357.

201. Id.

202. Burns, supra note 61 , at 378.

203. Id. at 380 . 
and shared decision-making. ${ }^{204}$ In the view of the study's authors, "when it comes to gender equality in the division of household chores and responsibilities, beliefs appear to have outrun practice."205

Catherine Kenney's 2006 study, which relied on data gathered in 2002 and 2003 as part of Fragile Families and Child Wellbeing national birth cohort study of parents and their children, is the most on point American study to date. ${ }^{206}$ Although the study is somewhat limited in its sample pool, ${ }^{207}$ the results are revealing. The study divided married couples into two categories: (1) those where the mother is married to the baby's father; and (2) those where the mother is married to a new partner. The results, which are summarized on Table 2, reveal that only a minority of women reported using the pooled money/equal control system. ${ }^{208}$ Most couples utilized some form of pooling - $83 \%$ of mothers married to the baby's father and $80 \%$ of mothers married to a new partner reported some type of pooling arrangement. ${ }^{209}$ These numbers are consistent with the findings from earlier studies. Kenney's study, however, went further and examined the types of pooling arrangements used. Taken as a whole, Kenney's study suggests that $65-71 \%$ of married couples with young children utilize an allocative system that tends to put the wife at a financial disadvantage. ${ }^{210}$

Table 2: Distribution of Allocative Systems Among Married Women with Children from FFCW Data

\begin{tabular}{|l|c|c|c|c|c|c|}
\hline \multicolumn{7}{|c|}{ Percentage Using Allocative System } \\
\hline Variable & $\begin{array}{l}\text { Separate, } \\
\text { Woman } \\
\text { Control }\end{array}$ & $\begin{array}{l}\text { Separate, } \\
\text { Man } \\
\text { Control }\end{array}$ & $\begin{array}{l}\text { Separate, Equal } \\
\text { Control (Partial } \\
\text { Pooling) }\end{array}$ & $\begin{array}{l}\text { Pooled, } \\
\text { Woman } \\
\text { Control }\end{array}$ & $\begin{array}{l}\text { Pooled, } \\
\text { Man } \\
\text { Control }\end{array}$ & $\begin{array}{l}\text { Pooled, } \\
\text { Equal } \\
\text { Control }\end{array}$ \\
\hline $\begin{array}{l}\text { Mother } \\
\text { Married } \\
\text { to Baby's } \\
\text { Father }\end{array}$ & $10 \%$ & $7 \%$ & $11 \%$ & $24 \%$ & $13 \%$ & $35 \%$ \\
\hline $\begin{array}{l}\text { Mother } \\
\text { Married } \\
\text { to New } \\
\text { Partner }\end{array}$ & $16 \%$ & $4 \%$ & $11 \%$ & $24 \%$ & $16 \%$ & $29 \%$ \\
\hline
\end{tabular}

204. $I d$.

205. $I d$.

206. Kenney, supra note 1.

207. Id. at 363 .

208. Id. at 368 .

209. Id.

210. See supra Table 2. 


\section{B. Equality Was Not a Goal: Legal \& Historical Analysis}

No state gave serious consideration to true egalitarianism. Likely the biggest concern for many legislators was enacting laws that were gender neutral on their face, while also maintaining the breadwinner's dominance in money management. Even those reformers who saw equality and egalitarianism as a laudable goal failed to view the law as a meaningful tool for implementing change. ${ }^{211}$ Commentators repeatedly - and erroneously - contended that women already participated in family finances in such a manner as to have achieved power parity with men. ${ }^{212}$ Reformers simply assumed that because women's place in the workforce and society had undergone some change that it had changed at home as well. ${ }^{213}$ But this was not true then and is not true now. Women's increased market participation had not resulted in egalitarian marital relationships during the reform era, nor has it resulted in widespread egalitarianism some forty years later.

1. Texas-The Dual Management/Two Fund Approach.-Texas, the first state to change its laws, never even attempted to enact legislation supporting an egalitarian view of the marriage relationship. Texas adopted a separate but equal management approach in an effort to maintain the status quo while throwing a bone to women advocating for change. In adopting an approach dubbed "dual management," or "the two fund approach," Texas gave women freedom from their husbands - not equality. No other community property jurisdiction overtly followed the Texas approach, but they are no less problematic.

The organized advocacy of Texas women led to reform years before other states even considered the issue. ${ }^{214}$ By the mid-1950s, women's groups in Texas - most notably the Texas Federation of Business and Professional Women's Club ("BPW") - sought to eliminate sex discrimination in the law. ${ }^{215}$

211. See, e.g., Arnold D. Kahn \& Paul N. Frimmer, Management, Probate and Estate Planning Under California's New Community Property Laws, 49 CAL. ST. B.J. 516, 518 (1974) (" $[\mathrm{I}] \mathrm{t}$ is difficult to imagine that the new law will have a significant effect on most households. Family finances are such a personal matter that 'management and control' is more a function of the relationship of the parties ... than it is of legislative fiat.").

212. See, e.g., Janet Mary Riley, Women's Rights in the Louisiana Matrimonial Regime, 50 TUL. L. REV. 557, 561 (1976).

213. See Radensky, supra note 141; Cynthia Shoss Wall, Management of the Louisiana Community Property System: The Need for Reform, 48 TUL. L. REV. 591, 592 (1974).

214. See, e.g., Ida M. Greenblatt, Texas' Dynamic Battle for Equal Legal Rights for Women, 50 Women L. J. 25 (1964) ("Early this year the Equal Legal Rights for Women's group marched in great number to Austin, Texas, to meet the Texas legislatures face to face, in their fight for equal rights. The battle was organized, planned, and carefully documented."); Jones, supra note 182, at 267 ("The Bar, however, gradually was forced to take action because of the increasing pressures which women's groups were bringing to bear on lawmakers for passage of the equal rights amendment.").

215. Joseph W. McKnight, Texas Community Property Law-Its Course of Development and Reform, 8 CAL. W. L. REV. 117, 128 (1971) [hereinafter McKnight, Texas Community Property 
"With 8,400 members and 185 clubs state-wide, the [BPW] had the potential for being a powerful legislative lobbying group and could be used to educate voters and legislators about pending bills."216 In 1957 the BPW asked an attorney, Hermine D. Tobolowsky, to work on a bill that would, among other rights, grant married women control over their own separate property. ${ }^{217}$ At the legislature, Ms. Tobolowsky was met with outright hostility. ${ }^{218}$ When Ms. Tobolowsky testified before a senate committee hearing in favor of the bill, the senators were not encouraging. One senator reportedly informed Ms. Tobolowsky that, "[w]omen are too stupid to handle property.", 19 This sentiment was a fairly common one. A 1964 poll conducted by the Texas Bar Journal found that members of the bar opposed equal rights for women by a vote of two-to-one. ${ }^{220}$ Texas women faced an uphill battle gain equal legal recognition and, understandably, egalitarianism within marriage - a loftier and more progressive goal - does not appear to have formed a major part of their platform.

Texas women had pressured the legislature to amend the state constitution in order to prohibit gender discrimination for many years. ${ }^{221}$ By the mid-1960s, legislators feared that they would not be reelected if they continued to oppose the amendment. $^{222}$ In an effort to avoid a constitutional amendment prohibiting gender discrimination generally, the legislature and the state bar association worked on a proposal to reform the state's community property laws in order to appease the state's women. ${ }^{223}$ The reforms were presented as the "answer [to] the demands for equality of both partners to the marital union" whose object was "to recognize that both spouses stand before the law in complete parity." ${ }^{224}$ Despite these claims, equality and parity were hardly present during the reform process nor in the resulting laws. The committee tasked with drafting the new laws consisted of four men and one woman. ${ }^{225}$ The committee was aided by a group of academic advisors consisting of six men and one woman. ${ }^{226}$ Not surprisingly, the reform — which was passed into law in 1967— did not provide for a true

Law]; McKnight, supra note 135, at 86.

216. Tai Kreidler, Hermine Tobolowsky: Mother of Texas's Equal Legal Rights Amendment, in The Human Tradition In TeXas, 209, 213 (1984).

217. Id.

218. Kimberly Garcia, Opportunities and Challenges: Women \& the Law Conference Fosters Professionalism, 55 TEX. B.J. 10 (1992).

219. Hermine Tobolowsky et al., Women Share Perspectives on Practicing Law Today, 55 TEX. B.J. 11, 12 (1992).

220. Referendum, Judicial Poll Results Told, 27 TEX. B.J. 227 (1964).

221. McKnight, Texas Community Property Law, supra note 215, at 128.

222. Id. at 12 n.74; Tobolowsky et al., supra note 219 , at 12.

223. McKnight, Texas Community Property Law, supra note 215, at 128-30.

224. Joseph W. McKnight, Recodification of Matrimonial Property Law, 29 TEX. B.J. 1000, 1000 (1966) [hereinafter McKnight, Recodification].

225. See id. at 1052-53 n.2.

226. Id. at 1053 n.3. 
egalitarian partnership between the spouses. ${ }^{227}$ Texas simply did not give women "an equal voice in the management of the community . . .."228 Rather, Texas adopted a dual management approach that divided the spouses' community property into two separate funds based on their source. ${ }^{229}$ The dual management approach was gender neutral on its face, but it quite obviously - and probably intentionally - worked to the disadvantage of most women. Dual management gave each spouse full control over his or her own earnings, regardless of gender. ${ }^{230}$ But, this approach simply allowed most husbands to carry on exactly as they had before the revisions. ${ }^{231}$ In short, the Texas legislature granted women independence from their husbands, but it did not put them on equal economic footing with them. The outcome in the other community property states is no different.

2. Arizona, California, Idaho, Louisiana, Nevada, New Mexico, and Washington-The Equal Management Approach.-Congress sent the federal Equal Rights Amendment ("ERA") to the states for consideration in 1972, paving the way for major revisions in the remaining community property jurisdictions. ${ }^{232}$ Anticipating the possible passage of the ERA and the expanding equal protection jurisprudence, all but one (Louisiana) of the remaining community property states revised their management laws between 1972 and 1975. ${ }^{233}$ California, Texas, and Idaho approved the ERA in 1972. ${ }^{234}$ New Mexico and Washington followed in 1973. ${ }^{235}$ Texas, New Mexico, and Washington also enacted amendments to their state constitutions guaranteeing equality of rights under the law. ${ }^{236}$ Although Arizona and Nevada never adopted the ERA, the threat of its passage and related pressures caused Arizona and Nevada to revise their management regimes in

227. See McKnight, Texas Community Property Law, supra note 215, at 138.

228. Huie, supra note 140, at 623.

229. See McKnight, Texas Community Property Law, supra note 215, at 138.

230. Id.

231. See Ronald G. Williams, Section 5.22 of the Texas Family Code: Control and Management of the Marital Estate, 27 Sw. L. J. 837, 840 (1973).

232. Roberta W. Francis, The ERA in the States, The Equal Rights AmEndment, http://www.equalrightsamendment.org/states.htm (last visited Feb. 22, 2014), archived at http://perma.cc/AY5A-LWDF.

233. Alan Pedlar, The Implications of the New Community Property Laws for Creditors' Remedies and Bankruptcy, 63 Cal. L. Rev. 1610, 1611 n.3 (1975).

234. Linda Napikoski, When Did States Ratify the ERA?, WOMEN's HISTORY AT ABOUT.COM, http://womenshistory.about.com/od/equalrightsamendment/a/When-Did-States-Ratify-ERA.htm (last visited at Feb. 22, 2014), archived at http://perma.cc/85D5-82PD.

235. Id.

236. "Equality of rights under law shall not be denied on account of the sex of any person." N.M. CONST. art. 2, § 18; "Equality under the law shall not be denied or abridged because of sex, race, color creed, or national origin." TEX. CONST. art. 1, $\S 3 \mathrm{a}$; "Equality of rights and responsibility under the law shall not be denied or abridged on account of sex." WASH. CONST. art. $31, \S 1$. 
1973 and 1974, respectively. ${ }^{237}$ Louisiana, whose revisions became effective in 1980, was, shamefully, the last to change its laws. ${ }^{238}$

These states debated a variety of approaches before adopting equal management. Examination of these legislative and scholarly debates demonstrates that true marital egalitarianism was not a goal of the resulting legislation. In many respects, the resulting legislation simply maintained existing male dominance while giving the law an appearance of constitutionality and equality.

A number of legislators and commentators favored the Texas dual management approach, ${ }^{239}$ which was also gaining popularity internationally. ${ }^{240}$ However, serious questions had subsequently arisen concerning the constitutionality of the dual management approach and states were hesitant to adopt it. ${ }^{241}$ Although the Texas law was gender neutral on its face, "in reality the spouse who stays in the home is going to remain economically dependent upon the spouse who receives financial reward for working outside the home."242 In the end, no state explicitly adopted Texas' approach.

An alternative proposal would require the joinder of the spouses in all transactions involving community property. ${ }^{243}$ Despite some academic support, the joinder approach was not seriously considered by any state. The joinder approach would, in theory, provide for true equality between the spouses - an outcome not desired by many legislators. ${ }^{244}$ The joinder approach also raised some practical problems. Requiring joinder on all community property transactions - particularly in the case of small, ordinary transactions - would be

237. See, e.g., Arizona Appellate Decisions 1972-73, 15 ARIZ. L. REV. 593 n.73 (1973).

238. See, e.g., Katherine S. Spaht, Background of Matrimonial Regimes Revision, 39 LA. L. REV. 323, 324-33 (1979).

239. See id. at 325 ("The Reporter favored equal powers of management of community property; the members of the Advisory Committee were divided as to the direction revision should take; and the Council appeared to favor a system 'whereby each spouse would exercise control over her or her own earnings."').

240. The dual management approach is also referred to as a deferred community property regime. See Jacques-Michel Grossman, Matrimonial Property Law Reform: Choosing a New Legal Regime, 8 Holdsworth L. ReV. 45 (1983); Gina Quijano, Matrimonial Property Law Reform in Canada: From Separate Property to Community Property with Joint Management, 13 Osgoode Hall L. J. 381, 393 (1975); Janet Mary Riley, Women's Rights in the Louisiana Matrimonial Regime, 50 TUL. L. REV. 557, 559(1976); Douglas H. Tess, Note, The Partnership of Acquests as the Proposed Legal Matrimonial Property Regime of the Province of Quebec, 14 MCGILL L. REV. 113, 114 (1968).

241. See Robert M. Mitchell, Note, Equal Rights and Equal Protection: Who Has Management and Control?, 46 S. CAL. L. REV. 892, 910-11 (1973).

242. Quijano, supra note 240, at 393.

243. See Anne K. Bingaman, The Effects of an Equal Rights Amendment on the New Mexico System of Community Property: Problems of Characterization, Management, and Control, 3 N.M. L. REV. 11, 39 (1973); Radensky, supra note 141, at 186.

244. Quijano, supra note 240, at 389. 
unduly cumbersome. ${ }^{245}$ Would the wife have to consent to her husband buying a cup of coffee on his way to work? Joint management also raised serious questions regarding who would arbitrate when the spouses were unable to agree on a transaction. ${ }^{246}$ Some commentators outright rejected egalitarianism on policy grounds arguing that "requiring consultation and agreement between the spouses for all transactions presume[d] that bad faith and lack of trust are the norm for the majority of married couples." ${ }^{247}$ One version of joint management proposed in California attempted to strike a balance. The proposal involved a system of modified joint control where either spouse could engage in transactions below a certain statutorily determined value, but joinder would be required for all others. ${ }^{248}$ Although this approach appealed to some legislators, it was ultimately unsuccessful. ${ }^{249}$

Another proposal - equal management - allowed either spouse, acting alone, to manage any aspect of the community property without the consent of the other spouse. ${ }^{250}$ A number of reformers and commentators - particularly women endorsed the equal management approach. ${ }^{251}$ Equal management was theoretically consistent with an egalitarian view of marriage:

A system of [equal] management has as its underlying premise the assumption that each spouse is of equal competence to make decisions affecting community property. It presumes trust and communication between the spouses. Just as the notion basic to business partnerships is that each partner will consult with the other before taking any action of major importance, the [equal] management concept in the marriage arena assumes that the spouses will similarly consult and agree. ${ }^{252}$

It is telling that no state seriously questioned the accuracy of the assumption on which equal management is premised - that spouses will consult and agree before making financial decisions. That assumption was patently false and it remains so today. ${ }^{253}$ The resulting laws, therefore, would do nothing to encourage communication and agreement between the spouses on important matters.

It is also telling that no state was willing to allow equal management to apply to all community assets. Some commentators, for example, argued that this

245. Bingaman, supra note 243, at 43; Radensky, supra note 141, at 186.

246. Bingaman, supra note 243 , at 43 .

247. Id.

248. See Mitchell, supra note 241, at 913-14.

249. Radensky, supra note 141, at 186; see also John A. Adamske, Equal Management and Control Under Senate Bill 569: 'To Have and To Hold' Takes on New Meaning in California, 11 SAN DiEGo L. REV. 999, 1002-03 (1974).

250. See Bingaman, supra note 243, at 44; Mitchell, supra note 241, at 914-15.

251. See, e.g., Bingaman, supra note 243, at 44 (endorsing such an approach); Spaht, supra note 238, at 325 (noting that the Reporter, Prof. Janet Mary Riley, supported this approach); Not Tea and Crumpets, Says Women's Coalition, TIMES-PICAYUNE, June 8, 1976, § 1, at 5.

252. Bingaman, supra note 243 , at 44.

253. See supra Part II.C, III.A. 
system would be problematic where one spouse (presumably the woman) was not adept at handling money. ${ }^{254}$ Others perceived some unfairness in allowing the non-bread earning spouse (the woman) to have equal access to the earnings. ${ }^{255}$ In the end, the equal management states adopted a sort of middle ground. Some transactions and assets were subject to equal management. Some transactions required the joinder of both spouses. Some transactions fell within the exclusive management rights of one spouse acting alone.

a. Equal management.-Equal management is the default rule of management in every state except Texas. ${ }^{256}$ Those acts and transactions that do not require joinder and are not subject to the exclusive management by one spouse are subject to the residual rule of equal management - a rule premised on a largely faulty presumption of equality between the spouses. As a practical matter, however, relatively few transactions actually fall within the scope of this residual rule.

b. Joinder required.-The equal management states require the joinder or consent of both spouses in a number of transactions. Joinder, in theory, furthers egalitarianism between the spouses. The joinder requirements that exist today, however, do not reflect any meaningful departure from the pre-revision management regime. The joinder requirements that survived the revision do not reflect any attempt by legislatures to increase the wife's participation in a couple's financial decisions. Rather, the joinder requirements reflect a view that the husband could (and would) take advantage of his otherwise powerless wife and that the legislature ought to step in to prevent those abuses in some limited circumstances. Retention of these joinder requirements simply reinforces the picture of the woman as the powerless spouse in need of the law's protection. These joinder requirements also seem to contradict the assumption of consultation and agreement upon which the equal management rule was premised because they assume that joinder is needed to ensure that both spouses have a voice in particular financial decisions. All equal management states require the joinder of both spouses in various transactions affecting community real property ${ }^{257}$-a protection already won by women in most community property states decades before the reform era. ${ }^{258} \mathrm{~A}$ handful of states continue to require joinder or concurrence in the transfer or encumbrance of household furnishings, ${ }^{259}$ a

254. Mitchell, supra note 241 , at 915.

255. Id.

256. Cynthia Samuel, Restoration of the Separate Estate from Community Property After the Equal Management Reform: Some Thoughts on Louisiana's Reimbursement Rules, 56 Law \& Contemp. Probs. 273, 274 (1993) (describing now Louisiana took a different approach than Texas).

257. See e.g. ARIZ. Rev. Stat. ANN. § 25-214 (2015); CAL. FAM. CODE § 1102 (West 2015); IDAHO CODE ANN. § 32-912 (West 2015); LA. Civ. CODE ANN. art. 2347 (2015); N.M. STAT. §40-313 (2015); NeV. ReV. StAT. $§ 123.230$ (2015); WASH. ReV. CodE $§ 26.16 .030$ (2015).

258. See supra Part II.B.

259. See Cal. Fam. Code $\S 1100(\mathrm{C})$ (West 2015); La. Civ. Code AnN. art. 2347 (2015) (requiring concurrence for the "alienation, encumbrance, or lease of . . f furniture or furnishings while located in the family home. . ..”); NEV. REV. STAT. § 123.230(5) (2015) (requiring 
requirement that had existed under prior law and that had been enacted to protect otherwise powerless women from being deprived of the bare necessities of life because of their husbands' improvidence or cruelty. ${ }^{260}$ Retention of this particular joinder requirement simply reinforces the picture of the woman as the powerless spouse and seems to contradict the assumption of consultation and agreement upon which the equal management rule was premised. The equal management states also carried forward various restrictions on a spouse's ability to make gratuitous transfers of community property to third parties. ${ }^{261}$ In some states the requirement of concurrence is a matter of statute. ${ }^{262}$ In others, it is a development of the state's jurisprudence. ${ }^{263}$

c. Exclusive management by one spouse.-A number of transactions and acts of management are subject to the exclusive management of one spouse - an approach that is the antithesis of egalitarianism. ${ }^{264}$ The transactions subject to these exclusive management rules are particularly problematic because of their importance to both the day-to-day and long term financial wellbeing of a family.

California, Louisiana, Nevada, and Washington specifically recognize a 'business exception' to management. ${ }^{265}$ In these states, the spouse who is the "manager" of a sole proprietorship has the exclusive right to engage in various acts of management affecting that business. ${ }^{266}$ This issue was the subject of considerable debate that was quite clearly gendered in nature. ${ }^{267}$ The (predominantely male) business community demanded the exclusive management approach to their business dealings. ${ }^{268}$ Businessmen wanted to ensure that they

concurrence for the sale or encumbrance of "community household goods, furnishings or appliances"); WASH. REV. CODE $§ 26.16 .030$ (5) (2015) (requiring concurrence for the sale or encumbrance of "community household goods, furnishings, or appliances, or a community mobile home....").

260. See supra Part II.B.

261. See supra Part II.B.

262. Cal. Fam. Code $\S 1100$ (b) (West 2015); La. Civ. Code art. 2349 (2015); Nev. Rev. STAT. § 123.230(3) (2015); WASH. REV. CODE § 26.16.030(2) (2015).

263. Estate of Hull, 885 P.2d 1153, 1156 (Idaho Ct. App. 1994); Roselli v. Rio Communities Serv. Station, Inc., 787 P.2d 428, 433 (N.M. 1990).

264. Cal. FAM. Code $\S 1100(d)$ (West 2015); La. CiV. Code AnN. art. 2350 (2015); NeV. REV. STAT. § 123.230(6) (2015); WASH. REV. CODE § 26.16.030(6) (2015).

265. CAL. FAM. CODE $\S 1100(\mathrm{~d})$ (“'AA] spouse who is operating or managing a business or an interest in a business that is all or substantially all community personal property has the primary management and control of the business interest."); LA. CIV. CODE art. 2350; NEV. REV. STAT. § 123.230(6); WASH. REV. CODE $§ 26.16 .030(6)$.

266. Cal. Fam. Code $\S 1100(d)$; La. Civ. Code art. 2350; NeV. Rev. Stat. § 123.230(6); WASH. REV. CODE $§ 26.16 .030(6)$.

267. Arnold D. Kahn \& Paul N. Frimmer, Management, Probate and Estate Planning Under California's New Community Property Laws, 49 CAL. StATE B. J. 516, 517 (1974).

268. See Adamske, supra note 249, at 1004; Harry M. Cross, 1972 Amendments to the Washington Community Property Law, 26 WASH. S. B. J. 9, 11 (1972) [hereinafter Cross, 1972 Amendments]. 
could continue to operate without the sudden interference of their wives. ${ }^{269}$ Creditors and other third parties wanted some assurance that the husband had the authority to continue to engage in ordinary business transactions without the consent of his wife. ${ }^{270}$ Critics argued that exclusive management allowed the manager spouse - typically the husband - to squander important community assets without the knowledge of the other spouse. ${ }^{271}$ As a compromise, the business exception states adopted procedural safeguards to "protect the nonacting spouse (and thus the community) from imprudent and arbitrary decisions involving 'blue chip' community assets." 272 California requires the managing spouse "give prior written notice to the other spouse of the sale, lease, exchange, encumbrance, or other disposition of all or substantially all of the personal property used in the operation of the business." 273 Louisiana requires the joinder of both spouses for the alienation, encumbrance, or lease of "all or substantially all of the assets of a community enterprise." ${ }^{274}$ Nevada and Washington require the consent of the nonparticipating spouse for transactions that are not in the ordinary course of business. ${ }^{275}$ Even with these limits in place, the business exception statutes remained controversial in academic writing; ${ }^{276}$ however, little litigation ensued in the following decades.

Today, many business owners elect to incorporate their sole proprietorships into limited liability companies ${ }^{277}$ — an option that was not available at the time of the revision. ${ }^{278}$ Management of community interests in corporations, partnerships, limited liability companies and other business entities typically falls under the exclusive management of one spouse because of concepts of privity and title. ${ }^{279}$ Once a spouse incorporates his sole proprietorship as a business entity, the procedural safeguards of the business exception no longer apply. Statutes in Louisiana and Washington make it clear that community personal property registered or titled in the name of one spouse is subject to that spouse's exclusive

269. Id.

270. Id.; see also Lydia Nayo, Revisiting Worth: The Copyright as Community Property Problem, 30 U. SAN. FRAN. L. REV. 153, 175 (1995).

271. Harry M. Cross, Equality for Spouses in Washington Community Property Law-1972 Statutory Changes, 48 WASH. L. REV., 527, 538 (1973) [hereinafter Cross, Equality for Spouses].

272. Id.

273. CAL. FAM. CODE $§ 1100(d)$ (West 2015).

274. LA. CIV. CODE ANN. art. 2347 (2015).

275. Nev. Rev. StAT. § 123.230(6) (2015), WASH. ReV. CODE $§ 26.16 .030(6)$ (2015).

276. Cross, Equality for Spouses, supra note 271, at 528.

277. Rodney D. Chrisman, LLCS Are the New King of the Hill: An Empirical Study of the Number of New LLCS, Corporations, and LPS Formed in the United States Between 2004-2007 and How LLCS Were Taxed for Tax Years 2002-2006, 15 FORDHAM J. CORP. \& FIN. LAW 459 (2010).

278. See Glen G. Morris \& Wendell H. Holmes, 8 La. Civ. L. Treatise, Business ORGANIZATIONS $\S 44.01$ (2014) (stating "LLCs were first introduced in the United States by Wyoming, in 1977').

279. See generally Richard W. Effland, Arizona Community Property Law: Time for Review and Revision, 1982 ARIZ. ST. L. J. 1 (1982). 
control. ${ }^{280}$ This includes interests in business entities. Basic title concepts and notions of privity mean that, as a practical matter, this is the case in all community property jurisdictions. ${ }^{281}$ As Professor Effland explained:

Management and control has two aspects. The first aspect involves only the husband and wife and seeks to determine which of them has the right to take action with respect to the property of the community. The second aspect involves relationships between the community and third persons, determining when a third person dealing with one of the spouses will be protected. In a sense, the second consideration will control. ${ }^{282}$

Indeed, this second aspect grants one spouse, acting alone, the exclusive management over virtually every item of valuable personal property that is associated with his or her name. ${ }^{283}$

As a practical matter, if stocks are registered in the name of one spouse, only that spouse can sell. True, the stock may be community property despite the paper title in the name of one spouse, and theoretically the non-titled spouse has 'equal' property to manage; but the broker will transfer only on the signature of the registered owner. ${ }^{284}$

This "practical matter" exception to equal management is more far reaching than registered stocks and business interests. ${ }^{285}$ It is an exception that swallows the default rule of equal management. "When the husband receives his regular paycheck into his own account, in what sense can it be said that the wife actually has 'equal' management rights to the community property earnings?"286 Ironically, ${ }^{287}$ it was Professor Pascal who coherently articulated the scope of this inequality: 'it is apparent that 'equal management' in the sense of equal and separate power in each spouse to alienate, encumber, or lease any community asset independently will exist as a matter of law in relatively few instances."288 In Professor Pascal's view, the only community assets that would fall under the rule of equal management were cash disbursements, commercial bearer paper,

280. LA. CIV. CodE ANN. arts. 2351, 2352 (2015); N.M. STAT. § 40-3-14 (2015).

281. Effland, supra note 279.

282. Id. at 15 .

283. Id.

284. $I d$.

285. Angela M. Bradstreet, Marital Property Law in England and California: A Comparative Study and Critique, 4 Hastings InT'L \& COMP. L. REV. 143, 169 (1980-1981).

286. Id.

287. Professor Pascal was outspoken in his opposition to the Equal Rights Amendment and reform of the community property management laws. See, e.g., Robert A. Pascal, Louisiana's 1978 Matrimonial Regimes Legislation, 53 TUL. L. REV. 105(1978) [hereinafter Pascal, Louisiana's 1978 Matrimonial Regimes Legislation]; Robert A. Pascal, Why I Oppose the ERA, 4 S.U. L. REV. 11 (1977-78).

288. Pascal, Louisiana's 1978 Matrimonial Regimes Legislation, supra, note 287, at 112 (1978). 
and "community assets considered to be neither furnishings for a family home nor business movables - perhaps jewelry, coin collections, clothing, sporting equipment, pleasure boats, guns, hobby workshop tools, books, and paintings owned as investments." 289 Indeed, this "practical matter" exception has completely eviscerated the concept of equal management in all meaningful respects.

\section{Existing Management Laws Perpetuate Gendered ALLOCATION OF RESOURCES}

Equal management applies to a shockingly small percentage of a couple's assets. Nearly every valuable asset is governed by one of the exceptions to the default rule of equal management. It is rather inaccurate, therefore, to continue to praise the community property system for being a "progressive" system that places "the spouses on the same plane of equality" and treats marriage as "an economic partnership in more than name or simple aspiration." 290

\section{A. Most Non-Financial Assets are Exempt from Equal Management}

Approximately two-thirds of a couple's net worth-is attributed to nonfinancial assets. ${ }^{291}$ The most commonly owned non-financial assets are vehicles, primary residence property, other residential property, and business equity. ${ }^{292}$ Table 3 shows the percentage of couples owning these assets and Table 4 illustrates the mean values of these assets. None of these assets is subject to equal management. Vehicles and business equity are typically subject to the rule of privity and fall under the exclusive management of the spouse whose name is on the title to the asset. Both types of residential property require the joinder of both spouses in most major acts of management.

Table 3: Percentage of Families Holding Non-Financial Asset in $\mathbf{2 0 1 0}^{293}$

\begin{tabular}{|l|l|l|l|l|}
\hline Family Type & Vehicles & $\begin{array}{l}\text { Primary } \\
\text { Residence }\end{array}$ & $\begin{array}{l}\text { Other } \\
\text { Residential } \\
\text { Property }\end{array}$ & Business Equity \\
\hline $\begin{array}{l}\text { Couples with } \\
\text { children }\end{array}$ & $94.8 \%$ & $75.6 \%$ & $15.5 \%$ & $17.0 \%$ \\
\hline $\begin{array}{l}\text { Couples } \\
\text { without } \\
\text { children }\end{array}$ & $93.2 \%$ & $79.7 \%$ & $22.6 \%$ & $19.5 \%$ \\
\hline
\end{tabular}

289. Id. at 112-13.

290. Samuel \& Spaht, supra note 17 , at 428.

291. Jesse Briker et al., Changes in U.S. Family Finances from 2007 to 2010: Evidence from the Survey of Consumer Finances, 98 FED. RES. Bull., No. 2, at 42 (June 2012), http://www. federalreserve.gov/pubs/bulletin/2012/PDF/scf12.pdf, archived at http://perma.cc/AGJ8-NBQ4.

292. Id. at 47.

293. Id. Other asset categories studied included bonds, other, and any financial asset. 
Table 4: Median Value of Asset for Families Holding Non-Financial Asset in 2010

\begin{tabular}{|l|l|l|l|l|}
\hline Family Type & Vehicles & $\begin{array}{l}\text { Primary } \\
\text { Residence }\end{array}$ & $\begin{array}{l}\text { Other } \\
\text { Residential } \\
\text { Property }\end{array}$ & $\begin{array}{l}\text { Business } \\
\text { Equity }\end{array}$ \\
\hline $\begin{array}{l}\text { Couples with } \\
\text { children }\end{array}$ & $\$ 21,300$ & $\$ 190,000$ & $\$ 120,000$ & $\$ 75,000$ \\
\hline $\begin{array}{l}\text { Couples without } \\
\text { children }\end{array}$ & $\$ 20,300$ & $\$ 180,000$ & $\$ 120,000$ & $\$ 109,000$ \\
\hline
\end{tabular}

\section{B. Most Financial Assets are Exempt From Equal Management}

On average, financial assets account for more than one-third of an American family's net worth. ${ }^{294}$ Although financial assets account for a smaller percentage of a couple's net worth than non-financial assets, access to financial assets is the more important indicator of egalitarianism. ${ }^{295}$ Access to financial assets impacts the wellbeing of the family and children and affects spousal-relationship quality. ${ }^{296}$ Yet, current law discourages and in some cases prohibits the equal participation of both spouses in decisions regarding financial assets. Today, financial assets are almost always subject to the exclusive management of one spouse unless the spouses affirmatively elect to take a different approach.

The most commonly owned financial assets are transaction accounts (checking accounts, savings accounts, and money market accounts) and retirement accounts (such as 401(k) accounts and IRAs). ${ }^{297}$ Table 5 shows the percentage of couples owning these assets and Table 6 illustrates the mean values of these assets. Financial assets - particularly transaction accounts and retirement accounts - are the types of assets that are involved in the day-to-day financial decisions of the spouses. ${ }^{298}$

Table 5: Percentage of Families Holding Financial Assets in $2010^{299}$

\begin{tabular}{|l|l|l|}
\hline Family Type $^{\mathbf{3 0 0}}$ & Transaction Accounts & Retirement Accounts \\
\hline Couples with children & $94.3 \%$ & $60.1 \%$ \\
\hline Couples without children & $95.9 \%$ & $61.6 \%$ \\
\hline
\end{tabular}

294. Id. at 23.

295. See supra Part I.

296. See supra Part I.

297. Id.

298. Id. at 26 (stating that " 92.5 percent of families had some type of transaction account.").

299. Id. at 28. Other asset categories studied included cash value life insurance, bonds, other, and any financial asset.

300. Id. at 7. "Couples" includes families in which the family head was either married or living with a partner. 
Table 6: Mean Value of Financial Asset Holdings in 2010 301

\begin{tabular}{|l|l|l|l|}
\hline Family Type & $\begin{array}{l}\text { All Financial } \\
\text { Assets }\end{array}$ & $\begin{array}{l}\text { Transaction } \\
\text { Accounts }\end{array}$ & Retirement Accounts \\
\hline $\begin{array}{l}\text { Couples } \\
\text { with children }\end{array}$ & $\$ 193,400$ & $\$ 3,800$ & $\$ 44,100$ \\
\hline $\begin{array}{l}\text { Couples } \\
\text { without } \\
\text { children }\end{array}$ & $\$ 209,000$ & $\$ 7,100$ & $\$ 77,400$ \\
\hline
\end{tabular}

1. Transaction Accounts-Exempt from Equal Management.-Transaction accounts - the very place where most couples store their day-to-day spending money - are wholly exempt from community property management laws. Applicable laws and bank policies often operate to discourage and, in some instances, outright prohibit, shared and informed decision-making by both spouses in an egalitarian manner. Our increased reliance on transaction accounts and direct deposit since the time of the community property reforms has exacerbated this inequity. Banks and other financial institutions operate according to a myriad of federal and state laws and internal procedures that rarely, if ever, consider a spouse's community property rights. No law requires a spouse to deposit community fund into a joint bank account with his or her spouse. Spouses are free to deposit their earnings and other community funds into any combination of joint accounts and individual accounts that they see fit and research shows that they most often do so in a manner that is detrimental to the wife.

Transaction accounts certainly existed at the time of the reform - but they have become more important in the past four decades. ${ }^{303}$ We have largely transitioned from a society paid in cash, to one paid by paper check, to one paid by direct deposit into a transaction account. ${ }^{304}$ A 2014 survey indicated that ninety-six percent of American workers receive their wages via direct deposit. ${ }^{305}$ Direct deposit was in its infancy during the reform era ${ }^{306}$ and, perhaps as a result, reformers paid very little attention to the rules governing transaction accounts.

301. Id. Data is from 2010.

302. Id. "Couples" includes families in which the family hear was either married or living with a partner.

303. See, e.g., Thomas Waterson, Those Direct-Deposit Paydays, Christian SCIEnCE MONITOR, (May 16, 1986), http://www.csmonitor.com/1986/0514/fwise35-f.html, archived at http://perma.cc/F6ZL-5YVK\#_blank (stating the rise in the direct deposit method of payment has increased the use of transaction accounts).

304. Id.

305. American Payroll AsSociation, 2014 'Getting Paid in America Survey Results', available at http://www.nationalpayrollweek.com/documents/2014GettingPaidInAmericaSurvey Results_FINAL_000.pdf, archived at http://perma.cc/HX22-L9DB\#_blank.

306. Id. 
Despite the increased use of transaction accounts and direct deposit, no legislature in a community property state has revised its community property management laws to address the changes. Similarly, many employers require their employees to participate in direct deposit, but no law requires married employees to deposit their earnings into a transaction account jointly held with their spouses. Nor do employers inquire into the title of the transaction account in an effort to ensure spousal access.

A review of several account disclosures promulgated by banks in community property states further illustrates the shocking lack of concern for community property rights or equal management. ${ }^{307}$ Indeed, none of these disclosure statements even reference community property principles. ${ }^{308}$ Rather, banks operating in community property jurisdictions operate just like banks in other states. ${ }^{309}$ Banks typically allow their customers to elect whether they prefer an individual account or a joint account. ${ }^{310}$ Individual accounts bear the name of a single person who is deemed the account owner. ${ }^{311}$ The individual named on the title to the individual account is the only person who has the right to withdraw funds from the account — regardless of his or her marital status or the community interest in the funds. ${ }^{312}$ Federal regulations actually mandate this type of treatment for all FDIC governed accounts. ${ }^{313}$ The applicable regulations explain that: "Community property funds deposited into one or more deposit accounts in the name of one member of a husband-wife community shall be treated as the individual account(s) of the named member ...." ${ }^{314}$ A spouse whose name is not on an individual account simply has no right to access the funds in that account

307. Bank of the West, Deposit Account Disclosure for Personal Accounts, 5-6 (Oct. 2011); CApital One BANK, Rules Governing Deposit Accounts, 9-11 (2014); COMMERCIAL BANK, Business AND PERSONAl Deposit ACCOUnt CONTRACT, 3-4; TeXAs CAPITAL BANK, CONSUMER TERMS AND Disclosures, 4-5 (2014) (all on file with author).

308. BANK OF THE WeSt, supra note 307, at 5-6; CAPITAL ONE BANK, supra note 307, at 9-11; COMMERCIAL BANK, supra note 307, at 3-4; TEXAs CAPITAL BANK, supra note 307, at 4-5.

309. BANK OF THE WEST, supra note 307 at 5-6; CAPITAL ONE BANK, supra note 307, at 9-11; COMMERCIAL BANK, supra note 307, at 3-4; TEXAS CAPITAL BANK, supra note 307, at 4-5.

310. BANK OF THE WeSt, supra note 307 at 5-6; CAPITAL ONE BANK, supra note 307, at 9-11; COMMERCIAL BANK, supra note 307, at 3-4; TEXAs CAPITAL BANK, supra note 307, at 4-5.

311. BANK OF THE WeSt, supra note 307 at 5-6; CAPITAL ONE BANK, supra note 307, at 9-11; COMMERCIAL BANK, supra note 307, at 3-4; TEXAs CAPITAL BANK, supra note 307, at 4-5.

312. BANK OF THE WEST, supra note 307 at 5-6; CAPITAL ONE BANK, supra note 307, at 9-11; COMMERCIAL BANK, supra note 307, at 3-4; TEXAS CAPITAL BANK, supra note 307, at 4-5. The "pay on death" or "POD" account is a common variation of the standard individual account. POD accounts allow the individual to designate a beneficiary to receive ownership of the account upon the death of the individual. The POD beneficiary has no rights to the account during the life of the individual. BANK OF THE WEST, supra note 307, at 5-6; CAPITAL ONE BANK, supra note 307, at 9-11; COMMERCIAL BANK, supra note 307, at 3-4; TEXAS CAPITAL BANK, supra note 307, at 4-5.

313. 12 C.F.R. $\S 330.6$ (2015).

314. Id. 
short of a court order. ${ }^{315}$ The unnamed spouse cannot even find out basic information about the account without the consent of the other spouse, despite owning a portion of the funds under applicable community property laws. ${ }^{316} \mathrm{~A}$ bank may even face liability for disclosing information about one spouse's accounts to the other spouse in the absence of a subpoena or other legal process. ${ }^{317}$

Joint accounts, in contrast, bear the names of two or more individuals. Typically, all of the people named on a joint account have equal rights to the funds in the account, ${ }^{318}$ an approach incentivized by the federal regulations. ${ }^{319} \mathrm{~A}$ couple could, of course, elect to deposit all of their funds into a single joint account and thereby adopt an egalitarian approach to money management. As Part I explains, however, couples rarely (if ever) take this approach. Thus, a couple's transaction account arrangement is more likely to perpetuate an unequal and gendered approach to money management, notwithstanding default state community property laws to the contrary.

2. Retirement Accounts-Exempt from Equal Management.-Retirement benefits earned during marriage are considered community property in every community property state. ${ }^{320}$ The law protects the rights of a divorced spouse to his or her share of retirement assets held in the name of the other spouse. ${ }^{321}$ Yet, the law specifically prohibits a spouse from participating in management of a retirement account during an in-tact marriage. Retirement accounts are subject to the exclusive management of the employee-spouse or the spouse whose name is on the title to the account. Not only does this arrangement discourage spouses from managing retirement assets in an egalitarian manner; it will typically favor the male spouse because of persisting lifetime gender pay disparities.

Retirement assets received little attention during the reform era probably because most voluntary employee retirement plans at the time were defined benefit plans. ${ }^{322}$ These plans typically pay the retired employee a lifetime fixed annuity that is determined by reference to years of employment and/or salary. ${ }^{323}$ Management is not a particularly meaningful attribute of employee participation in defined benefit plans because these plans require little, if any, decision making

315. Id.

316. Id.

317. Conner v. Conner, 594 So. 2d. 1039, 1044-45 (La. App. Ct. 3 Cir. 1992).

318. See supra note 307 . Joint accounts can also bear beneficiary or survivor designations as in the case of Joint Tenants with Right of Survivorship Accounts. Id.

319. See 12 C.F.R. $\S 330.9$ (2015).

320. See Samuel \& Spaht, supra note 17, at 432.

321. See id.

322. Barbara A. Butrica et al., The Disappearing Defined Benefit Pension and its Potential Impact on the Retirement Incomes of Baby Boomers, 69 Soc. SEC. Bull. No. 3 (2009), https://www.socialsecurity.gov/policy/docs/ssb/v69n3/v69n3p1.pdf, archived at http://perma.cc/494P-VYPX.

323. Id. 
on the part of the employee. ${ }^{324}$

In the past forty years, however, defined contribution plans have begun to replace defined benefit plans. ${ }^{325}$ The growing popularity of defined contribution plans has "shift[ed] the responsibility for managing retirement assets from the professional money managers who oversee defined benefit plan investments to individual participants in defined contribution plans." 326 As a result, management is an important attribute of ownership of most defined contribution plans. ${ }^{327}$ The plan participant must decide what percentage of his current earnings he will invest in the plan each year. ${ }^{328}$ The plan participant must also decide how to invest his savings and manage those investments throughout the course of saving for retirement. ${ }^{329}$ Yet, these plans have been specifically designed to thwart the equal participation by both spouses in those very acts of management.

Due to a combination of state and federal regulations and privity of contract principles, the plan participant has the exclusive right to manage his defined contribution plan-regardless of his marital status. The decision whether to participate in the plan, what percentage of current earnings to invest in the plan, and how to allocate those investments rests squarely with the individual participating in the plan. ${ }^{330}$ Unlike transaction accounts, retirement plans have no joint ownership or title option that would allow even allow equal management. ${ }^{331}$ The law, therefore, essentially prohibits egalitarian participation by both spouses in the management of retirement assets - an obviously unsound policy.

\section{CONCLUSION}

The movement to "reform" the management of marital property has done little to alter the fundamental inequality that prompted reform in the first place. Legislative changes to management rules reflected the presumption that women would obtain greater control over their money as they began to earn more. But that presumption has proven untrue. While the earnings gap between men and women has narrowed, the power gap with respect to the management of funds has not.

Research consistently demonstrates three things:

(1) Egalitarian management of a couple's resources has a positive impact on their relationship, their wellbeing, their family, and society as a whole;

324. Id.

325. $I d$.

326. James Poterba et al., Lifecycle Asset Allocation Strategies and the Distribution of 401( $k$ ) Retirement Wealth, NBER, 1 (2006).

327. See id. at 1-2.

328. Id.

329. Id.

330. Other considerations may affect plan participation. See, e.g., 26 U.S.C. $\S \S 408 \mathrm{a}, 415$ (2015) (limiting annual contributions).

331. Poterba et al., supra note 326. 
(2) Gendered and unequal management of a couple's resources has a negative impact on their relationship, their wellbeing, their family, and society as a whole; and

(3) Given the option, couples tend to elect harmful gendered and unequal management of their resources.

Legislation has not only failed to address the problems revealed by this research, in many instances the inequality has been mandated by legislation. Community property laws have failed to deliver on their promise of equality and partnership and can no longer be called progressive or beneficial to women. Today, they are quite the opposite. Because the problem of gender inequity remains embedded in the bedrooms and bank accounts of American families decades after reforms, the need for a new era of reform is upon us. 